\title{
Photosynthetic pigments in acid mine drainage: Seasonal patterns and associations with stressful abiotic characteristics
}

\author{
Patrícia Gomes a , Teresa Valente ${ }^{\mathrm{a},{ }^{*}}$, Dulce Geraldo ${ }^{\mathrm{b}}$, Catarina Ribeiro ${ }^{\mathrm{b}}$ \\ a ICT, Institute of Earth Sciences, Pole of University of Minho, Universidade do Minho, Campus de Gualtar, 4710-057, Braga, Portugal \\ ${ }^{\mathrm{b}}$ Chemistry Center, Universidade do Minho, Campus de Gualtar, 4710-057, Braga, Portugal
}

\section{H I G H L I G H T S}

- Acid mine drainage indicators show relationship with chlorophyll $a$.

- The more contaminated the environment, more chlorophyll $a$ was produced.

- Strong pH and potentially toxic elements dependency of chlorophyll $a$ production.

- Higher amount of chlorophyll $a$ in dry season.

- Higher chlorophyll $a$ production in low-flow water regime.

\section{A R T I C L E I N F O}

\section{Article history:}

Received 6 May 2019

Received in revised form 29 July 2019

Accepted 4 September 2019

Available online 5 September 2019

Handling Editor: Martine Leermakers

Keywords:

Photosynthetic pigments

Chlorophyll $a$

Acid mine drainage (AMD)

pH-dependency

Indicators

\begin{abstract}
A B S T R A C T
Acid mine drainage represents an extreme type of water pollution. The environments develop especial hydrochemical and ecological characteristics, such as high concentrations of acidity and low biodiversity, with dominance of acidophilic organisms.

Ecological criteria are assuming increasing relevance for assessing water quality, including in acid mine drainage-affected systems. Photosynthetic pigments, like chlorophyll, could be considered in this context as they are generally used to estimate phytoplankton biomass.

The present work was focused on acid mine drainage and their relationships with chlorophyll $a$. It was developed in the historic mine of São Domingos (Iberian Pyrite Belt, SW Europe). The methodological approach comprised two sampling campaigns (October and February) to represent seasonal behaviour. The diversity of hydrological conditions was also considered through sampling sites established in the pit lake, acidic lagoons and affected stream. Hydrochemistry and chlorophyll $a$ were analysed. The obtained results revealed very low $\mathrm{pH}$ values, with a minimum of 2.1. In general, hydrochemistry indicates higher concentrations of pollutants in summer. One of the sampling point, located in an acidic lagoon, stood out by highest concentrations, presenting maximum of sulfate $(6564 \mathrm{mg} / \mathrm{L})$, As $(6.26 \mathrm{mg} / \mathrm{L})$, and metals like $\mathrm{Al}(675 \mathrm{mg} / \mathrm{L}), \mathrm{Cd}(1,30 \mathrm{mg} / \mathrm{L}), \mathrm{Zn}(199 \mathrm{mg} / \mathrm{L})$. These highest concentrations coincided with the maximum concentration of chlorophyll $a(113 \mu \mathrm{g} / \mathrm{L})$. The results suggested that the more contaminated the environment, more chlorophyll $a$ was produced. Factor analyses emphasised the relationships between acid drainage properties and the photosynthetic activity, indicating a strong $\mathrm{pH}$ dependency of chlorophyll $a$ production.
\end{abstract}

๑) 2019 Elsevier Ltd. All rights reserved.

\section{Introduction}

One of the most extreme environments caused by human actions is produced by acid mine drainage (AMD), mainly related to legacy of historic coal and metals mining (De Vallejuelo et al., 2017;

\footnotetext{
* Corresponding author.

E-mail address: teresav@dct.uminho.pt (T. Valente).
}

Gomes et al., 2018; Olías et al., 2019; Nordin et al., 2018; SánchezPeña et al., 2018). AMD results from the oxidative dissolution of sulfides in a process with a strong biochemical component, as it is accelerated by the presence of microorganisms (e.g. Nordstrom and Southam, 1997). The complex cyclic reactions of AMD mobilize acidity, sulfate and potentially toxic elements (PTE). The generation and reaction mechanisms that control evolution of AMD have long been studied (e.g. Keith and Vaughan, 2000; McKibben and Barnes, 
1986; Singer and Stumm, 1970).

As a consequence of this type of pollution, biodiversity of aquatic ecosystems is severely constrained. Despite the stressful conditions, they are highly populated by acidophilic algae that could help to assess contamination by AMD (e.g. Valente and Gomes, 2007). In fact, European Water Framework Directive (WFD, European Commission 2000) considers the need for ecological criteria for studying the quality of water bodies.

Phytoplankton contains pigments that vary with environmental conditions, such as water properties and climate, among others. Chlorophyll $a$ is the main photosynthetic pigment, being widely used to estimate phytoplankton biomass in surface fresh waters (Boyer et al., 2009; Breuer et al., 2017; Pridmore and Hewitt, 1984).

In AMD, identification of acidophilic algal communities has been undertaken in various regions of the world (e.g. Gomes and Valente, 2019; Levings et al., 2005, Novis and Harding, 2007) including in the Iberian Pyrite Belt (IPB) (e.g. Aguilera et al., 2006; Amils et al., 2011; Sabater et al., 2003,; Valente et al., 2016). However, the photosynthetic capacity and pigments' composition are not so often studied. The lower knowledge about pigments behaviour may be related to their degradability in such acidic waters. Sabater et al. (2003) refer the difficulty to obtain consistent measurements of chlorophyll $a$ in AMD. Also, Corcoll et al. (2012) report the probability of degradation of chlorophyll in an extreme acid and metallic environment. Therefore, the study of pigments' composition in AMD still is a relevant and demanding subject of research. Moreover, relationships with abiotic factors and their role as ecological indicators under AMD conditions remain slight explored.

The research was performed in São Domingos, an abandoned mining complex in the Portuguese section of the Iberian Pyrite Belt (Fig. 1). The following main specific objectives were defined: i) to assess contribution of potentially toxic elements to the aquatic ecosystem; ii) to analyze concentration and seasonal trends of photosynthetic pigments in relation to hydrochemistry and hydrology; iii) to investigate relationships between the degree of

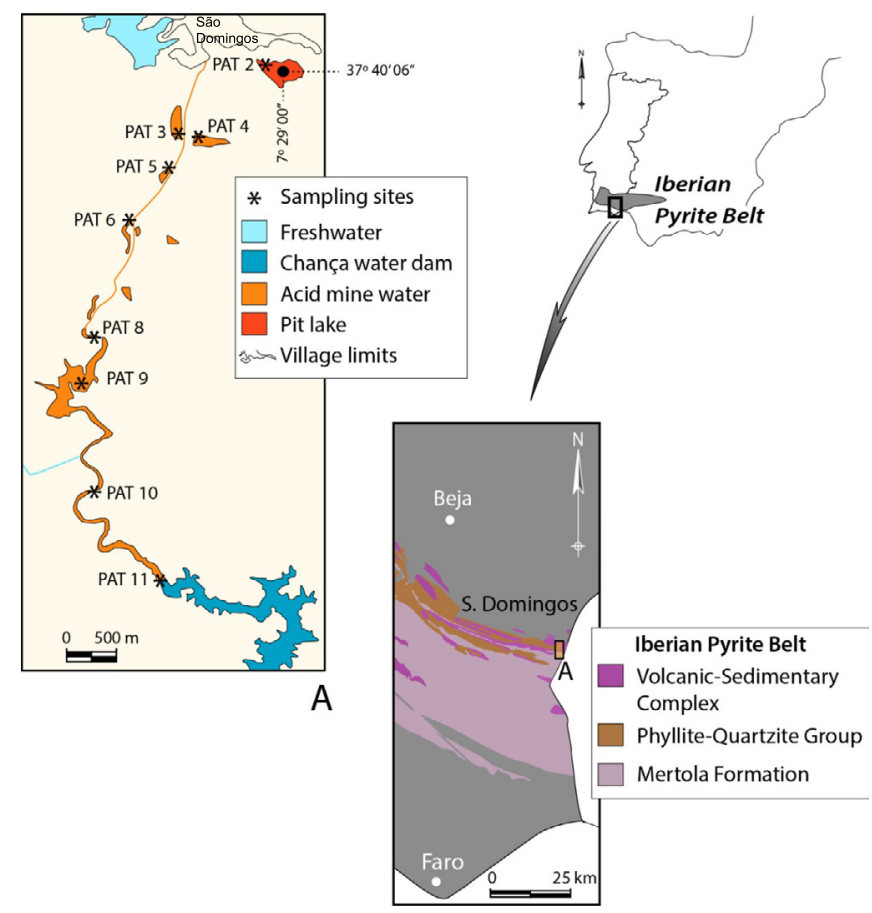

Fig. 1. Location of the study area in the Portuguese sector of the Iberian Pyrite Belt. Sampling sites in the São Domingos complex are also represented (PAT2-PAT11).
AMD contamination and the production of chlorophyll $a$.

\section{Methodology}

\subsection{Study site}

São Domingos is a massive sulfide mine located in the southwestern Portugal, near Mértola (Fig. 1). It belongs to the Iberian Pyrite Belt (IPB), known as one of the biggest metallogenic provinces in the world (Barriga, 1990; Inverno et al., 2015). The mine dates back to pre-Roman times and remained in activity until 1966, when it was definitely ceased. The geology of the IPB as well as of the São Domingos ore deposit has been detailed described by other authors (Matos et al., 2012; Sáez et al., 1999). The presence of massive sulfides is the most relevant issue for this study, since they represent strongly reactive wastes dispersed by the mining complex. These accumulations of mine-wastes drain their leachates to a small stream and mine dams (Fig. 1), promoting contamination (Abreu et al., 2010; Gomes et al., 2019).

Strong ochre colour associated with iron concentrations and deposition of iron oxyhydroxides are typical features of AMD (Fig. 2 a, b). Also, biomass production could be documented by blooms of green filamentous algae in different stages of maturity (Fig. 2 c-f).

The climate of the region is typical of the Mediterranean area. The annual average air temperature is $17.6^{\circ} \mathrm{C}$, and annual precipitation is $559 \mathrm{~mm}$. With hot summers $\left(30^{\circ} \mathrm{C}\right)$ and cold winters $\left(12^{\circ} \mathrm{C}\right)$, it can be divided into two distinct seasons: a wet period from November to April and a dry period from May to October (Abreu et al., 2008).

Specifically, it should be pointed out some meteorological data for the present research: in the summer of 2017 (between May and October 2017) the average temperature was of $23^{\circ} \mathrm{C}$, with very low precipitation value ( $\max 6.6 \mathrm{~mm}$ ). The first rains occur in February 2018. In fact two days of field campaign coincided with this rainy event. In these consecutive days there were 6.8 and $22.1 \mathrm{~mm}$, with a temperature around $12^{\circ} \mathrm{C}$ (IPMA, 2018).

\subsection{Sampling and analytical methods}

Two sampling campaigns were performed in order to represent dry and wet periods, respectively in October 2017 (Oct/17) and February 2018 (Feb/18). The nine sampling sites were established to cover distinct hydrological conditions (Fig. 1): the pit lake that resulted from the flooding of the open-cut (PAT2), several locations in the AMD-stream that receives leachates from the mine wastes (PAT6, PAT8, PAT10, PAT11), and the acidic lagoons that are abandoned water dams (PAT3, PAT4, PAT5, PAT9). There is no direct connection between the sampling locations, except for the four sites in the AMD-stream. Also, the pit lake as well as the four lagoons is treated as an isolated sampling site.

At each site, water samples were collected for analyses of the photosynthetic pigments (chlorophyll $a$ and pheophytin) and for chemical analyses. Sampling, treatment, and analytical procedures were performed according with European Committee for Standardization (2003) and APHA (2012). Although the photosynthetic pigments were analysed in water, the samples contain all type of floating cells, including filamentous algae detached from substrates.

\subsection{Chlorophyll $a$ and pheophytin extraction}

For the analyses of the photosynthetic pigments, $5 \mathrm{~L}$ of water were collected and stored in sterilised polyethylene containers. The samples were kept in refrigeration conditions and protected from 

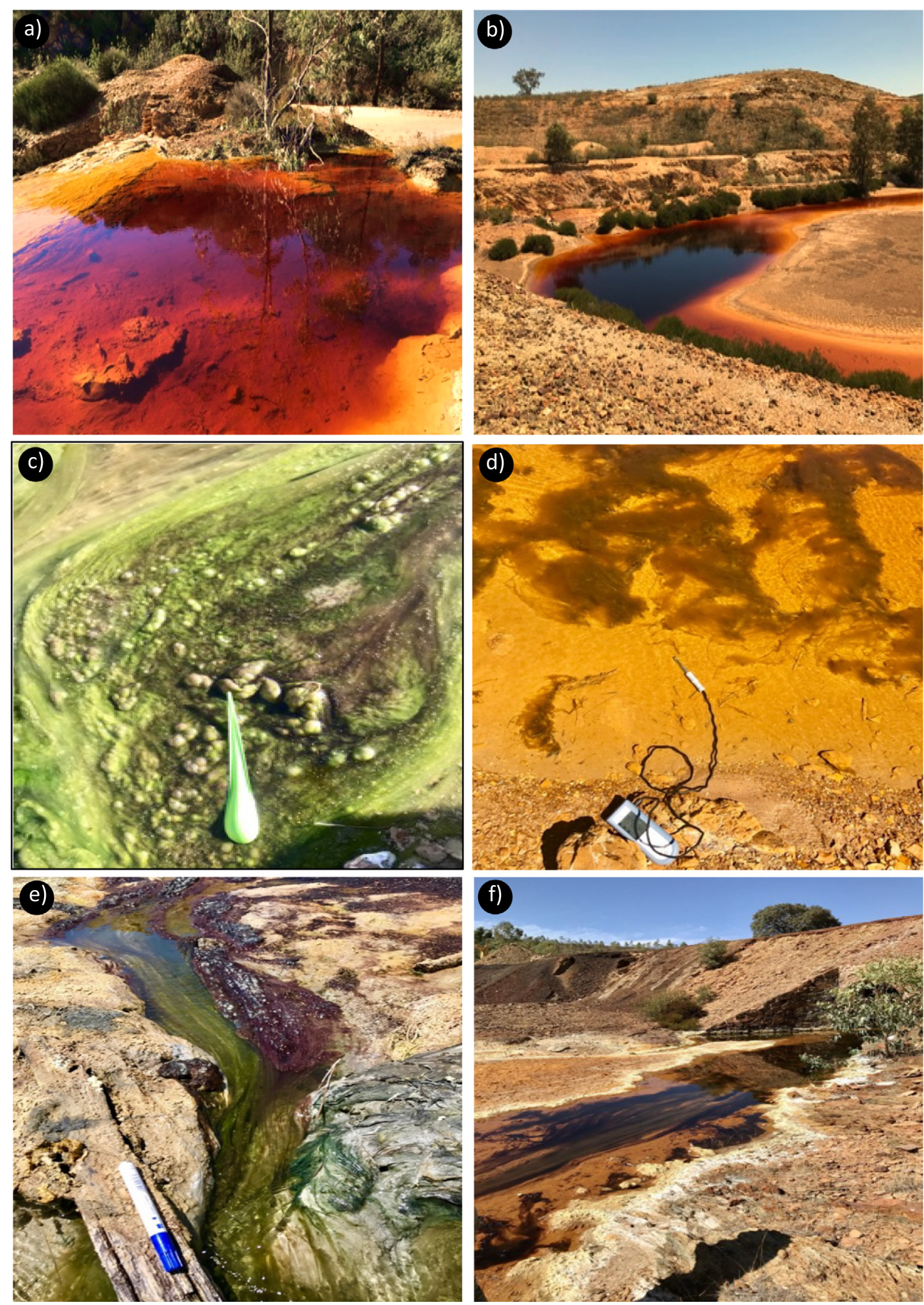

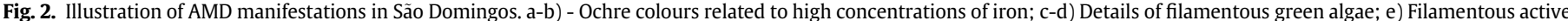
green algae in coexistence with aged subpopulation (brown patches); f) Senescence of algal communities. 
light to avoid degradation until arriving at the laboratory. Following the field collection, samples for pigment extraction were filtered in a volume between 250 and $1000 \mathrm{~mL}$ using a glass filter with $0.45 \mu \mathrm{m}$ porosity and reduced vacuum pressure. Filters were then stored at $-20^{\circ} \mathrm{C}$, until analysis. In accordance with the Standard Methods (10200H) (APHA, 2012), the pigments were extracted in replicates from the plankton concentrated with aqueous acetone (90\%), and subsequently stored in a dark environment at $<6{ }^{\circ} \mathrm{C}$ during $24 \mathrm{~h}$.

The extract was analysed using a fast and reliable spectrophotometric method commonly applied to measure chlorophyll $a$ and estimate phytoplankton. . The extract absorbance was determined with a Genesys 20 Thermo Spectronic spectrophotometer. A special care was taken to ensure a correct measurement of undegraded chlorophyll $a$. The concentrations of chlorophyll $a$ and pheophytin were estimated by spectrophotometric readings before and after acidification of the sample with $\mathrm{HCl} 0.1 \mathrm{~mol} \mathrm{~L}^{-1}$, in order to prevent an overestimation of the concentration of chlorophyll $a$. Acidification allows the exclusion of pheophytin, which presents absorption in the same wavelength range. The concentrations of the two pigments were estimated through the equations proposed by Lorenzen (1967)

\subsection{Chemical analysis of water samples}

At the same sites and periods used for pigments analyses, in situ parameters were measured and water samples were collected for determination of AMD properties. For the present work $\mathrm{pH}$ and electrical conductivity (EC) were recorded on-site, with a portable meter Thermo Scientific Orion. Two sterilised polyethylene containers were used to store water samples for further analyses. One $(100 \mathrm{~mL})$ was filled with $0.45 \mu \mathrm{m}$ filtered water and acidified with suprapur acid nitric $75 \%$ to obtain a $\mathrm{pH}<2$, in order to prevent metals precipitation and bacterial growth. The other $(500 \mathrm{~mL})$ was used for sulfate and acidity determinations. All water samples were preserved at below $6^{\circ} \mathrm{C}$ in a refrigerator until analysis.

Sulfate was determined by turbidimetric method (Standard Methods $4500 \mathrm{E}$ ) and total acidity by volumetric determination
(APHA, 2012; ASTM, 1992).

Concentration of major metals and potentially toxic elements ( $\mathrm{Na}, \mathrm{Al}, \mathrm{Mg}, \mathrm{Mn}, \mathrm{Ca}, \mathrm{Fe}, \mathrm{As}, \mathrm{Cd}, \mathrm{Co}, \mathrm{Ni}, \mathrm{Cu}, \mathrm{Zn}$, and $\mathrm{Pb}$ ) were obtained by inductively coupled plasma optical or mass spectroscopy (ICPOES/MS). These analyses were performed by an accredited laboratory (Activation Laboratory, Lda - Actlabs, Canada), with accuracy obtained by using certified standards (IV-STOCK-1643 (ICP/MS) Cert).

All the reagents used were of analytical grade or of suprapur quality (Merck, Darmstadt, Germany) and standard solutions were Merck AA Certificate. Milli-Q water was used in all experiments. As for ICP, blanks, replicates and stock solutions were used to assess quality control of the results. The accuracy of the methods was verified using certified standards. The measurement precision was within relative standard deviation (RSD) of $5 \%$ for all methods.

\subsection{Statistical analysis}

For statistical treatment, a set of typical indicator parameters for AMD were selected, in addition to chlorophyll $a$. Thus, the following variables were used: $\mathrm{pH}, \mathrm{EC}$, acidity, $\mathrm{SO}_{4}, \mathrm{Al}, \mathrm{Mg}, \mathrm{Mn}, \mathrm{Ca}, \mathrm{Cd}, \mathrm{Fe}, \mathrm{Cu}$, $\mathrm{Zn}$, and chlorophyll $a$. Factor analysis was performed with Varimax rotation and the Bartlett method. The statistical treatment was performed with the SPSS Release 24.0 software.

\section{Results and discussion}

\subsection{Acid mine drainage properties}

The general properties of the analysed waters are represented in Fig. 3, illustrating the seasonal behaviour of typical indicator parameters (e.g. García-Lorenzo et al., 2016), such as pH and EC, sulfate and acidity. In the dry season, the $\mathrm{pH}$ is $<2.5$ at almost all sites, with the exception of PAT6 and PAT11 (with pH-values around 3). The maximum $\mathrm{pH}$ was registered in February at PAT6 ( $\mathrm{pH} 3.6)$. Therefore, the radial representations reveal that all sites present higher $\mathrm{pH}$ in February. In fact, attending to the logarithmic nature of the $\mathrm{pH}$, the observed range $[2.1,3.6]$ represents a considerably
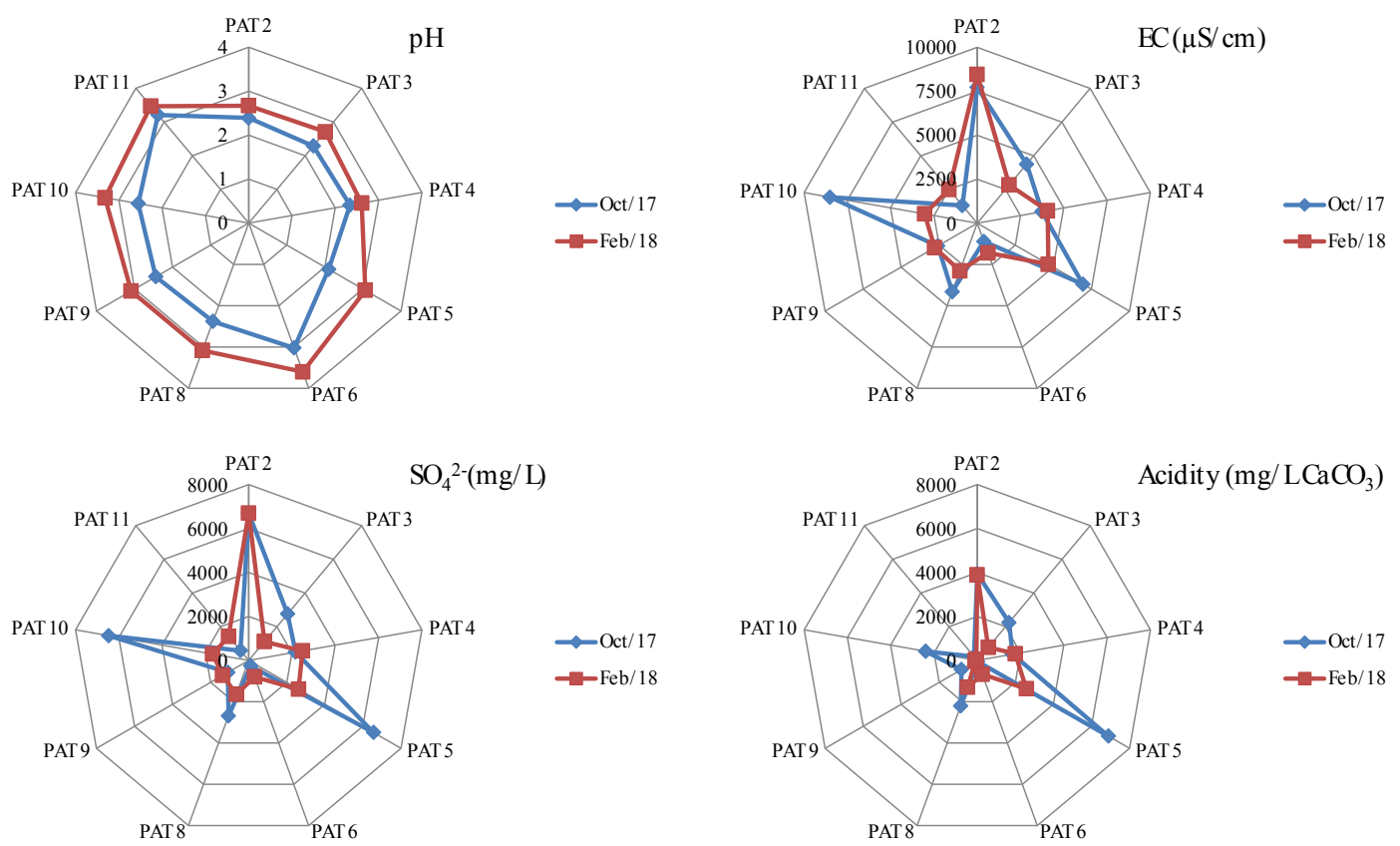

Fig. 3. Seasonal behaviour of pH, EC (Electrical Conductivity), sulfate, and acidity. 
Table 1

Major cations and potentially toxic elements in the two sampling campaigns.

\begin{tabular}{|c|c|c|c|c|c|c|c|c|c|c|}
\hline \multirow[t]{2}{*}{ Campaign } & \multirow[t]{2}{*}{ Samples } & $\mathrm{Al}$ & $\mathrm{Mg}$ & Mn & $\mathrm{Ca}$ & $\mathrm{Fe}$ & As & $\mathrm{Cd}$ & $\mathrm{Cu}$ & $\mathrm{Zn}$ \\
\hline & & \multicolumn{9}{|c|}{$(\mathrm{mg} / \mathrm{L})$} \\
\hline \multirow{9}{*}{ Oct/17 } & PAT 2 & 295 & 787 & 150 & 646 & 876 & 1.62 & 0.928 & 77.8 & 158 \\
\hline & PAT 3 & 251 & 169 & 14.7 & 163 & 170 & 25.8 & 36.2 & 22.2 & 10.5 \\
\hline & PAT 4 & 176 & 189 & 30.0 & 105 & 120 & 15.0 & 103 & 1.81 & 83.2 \\
\hline & PAT 5 & 675 & 252 & 37.2 & 205 & 801 & 6.26 & 1.30 & 83.9 & 199 \\
\hline & PAT 6 & 7.14 & 35.7 & 3.50 & 36.3 & 3.84 & 0.003 & 0.009 & 0.614 & 1.85 \\
\hline & PAT 8 & 238 & 123 & 10.6 & 189 & 193 & 96.5 & 74.6 & 1233 & 29.4 \\
\hline & PAT 9 & 90.3 & 40.1 & 3.34 & 57.8 & 56.9 & $<0.003$ & 0.047 & 7550 & 10.0 \\
\hline & PAT10 & 296 & 636 & 42.8 & 658 & 112 & 0.072 & 0.204 & 13.0 & 37.6 \\
\hline & PAT 11 & 41.6 & 40.4 & 3.08 & 62.7 & 15.5 & 0.066 & 0.026 & 2.33 & 5.14 \\
\hline \multirow[t]{9}{*}{ Feb/18 } & PAT 2 & 206 & 659 & 135 & 490 & 711 & 820 & 899 & 74.4 & 140 \\
\hline & PAT 3 & 85.4 & 57.9 & 6.38 & 80.1 & 22.1 & $<0.003$ & 21.0 & 7.78 & 5.21 \\
\hline & PAT 4 & 166 & 138 & 29.5 & 69.6 & 116 & $<0.003$ & 111 & 2.17 & 82.2 \\
\hline & PAT 5 & 275 & 112 & 17.0 & 115 & 184 & 670 & 230 & 30.5 & 38.3 \\
\hline & PAT 6 & 56.1 & 42.3 & 4.34 & 51.3 & 32.0 & 100 & 60.0 & 6.51 & 11.7 \\
\hline & PAT 8 & 107 & 60.3 & 9.30 & 80.5 & 147 & 50.0 & 65.0 & 10.0 & 21.3 \\
\hline & PAT 9 & 94.9 & 42,7 & 5.33 & 56.6 & 96.4 & 100 & 66.0 & 11.6 & 15.8 \\
\hline & PAT10 & 122 & 109 & 8.28 & 144 & 23.7 & 540 & 171 & 10.1 & 21.8 \\
\hline & PAT 11 & 711 & 101 & 5.57 & 135 & 2.91 & 15.0 & 90.0 & 6.33 & 12.7 \\
\hline
\end{tabular}

high concentration range of $\mathrm{H}^{+}$, able to impose relevant biogeochemical and mineralogical differences between the analysed sites, as modelled by Valente and Gomes (2009).

PAT5 and PAT2, followed by PAT10 stand out in both campaigns, with highest concentrations of acidity, sulfate, or EC (e.g. $\mathrm{SO}_{4}$ around $7700 \mathrm{mg} / \mathrm{L}$ ).

Table 1 shows concentration of major cations and of potentially toxic elements (PTE), such as As, Cd, and Zn. The results demonstrate the contamination by As and metals, typical of AMD as observed in other parts of the world (e.g. Dutta et al., 2017, Olías et al., 2019; Pérez-Sirvent et al., 2016; Silva et al., 2013). In addition to those elements, the high concentrations of $\mathrm{Al}$ and $\mathrm{Mg}$ should be emphasised. The spatial pattern (Fig. 1, for location) indicates highest concentrations in PAT2 (pit lake), PAT5 (acidic lagoon), and PAT10 (stream), as illustrated by the sum of selected PTE in Fig. 4.

Several authors document high degrees of contamination by AMD in dry and prolonged periods (Alpers et al., 1994; Nordstrom, 2009). On the contrary, lower concentrations in the wet season may be a response to dilution due to the occurrence of precipitation. This seasonal pattern can be observed through the sum of PTE (Al, $\mathrm{Cu}, \mathrm{Zn}, \mathrm{As}, \mathrm{Cd}$ ) in Fig. 4. However, PAT6 and PAT11 are exceptions, with higher concentrations of most of the elements in February. Specifically, in PAT11 some elements present more than the double of concentrations than in October. This may be justified by a special meteorological circumstance that occurred during the February campaign, specifically a sudden rainfall event. Therefore, some sites were sampled before the rainfall, while PAT6 and PAT11 were sampled after this event. The known phenomenon of the "first-

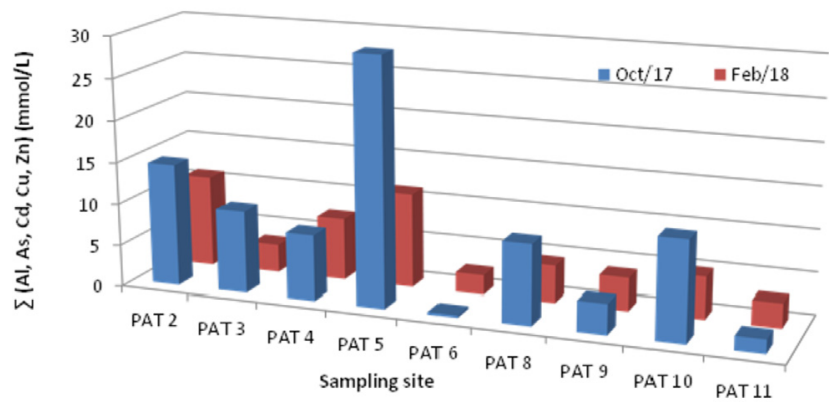

Fig. 4. Sum of potentially toxic elements in dry (Oct) and wet (Feb) seasons. flush" (e.g. Aldous, 1987, Nordstrom, 2009, Younger, 1997) may have influenced the results due to dissolution of secondary sulfates, identified by Gomes et al. (2017) in the São Domingos mine. This phenomenon, often reported (e.g. Moncur et al., 2015; Wolkersdorfer, 2008) may promote rapid modifications in hydrochemistry of AMD, both in underground and surface waters. For example Perry and Rauch (2013) refer the sudden large increase of metals associated with rapid flushing events.

\subsection{Photosynthetic pigments}

Fig. 5 represents the concentration of chlorophyll $a(\mathrm{Chl} a)$ and its main degradation product (pheophytin - Feo). The sampling site PAT5 has the highest concentration in both campaigns with about
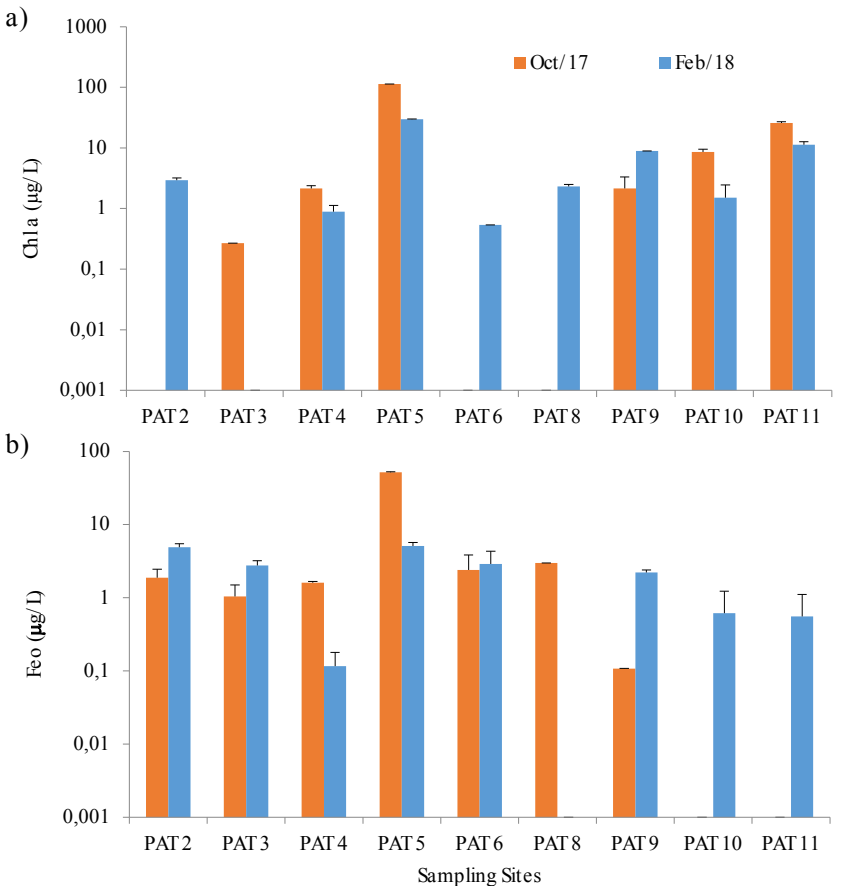

Fig. 5. Average and standard deviation $(n=3)$. a) chlorophyll $a(\mathrm{Chl} a)$ and b) pheophytin (Feo) 
113 and $30 \mu \mathrm{g} / \mathrm{L}$ of $\mathrm{Chl} a$, in October and February, respectively. In general, in the dry season the concentration of Chl $a$ follows the trend: PAT5 $>$ PAT $11>$ PAT $10>$ PAT $4=$ PAT9 $>$ PAT3. Chl $a$ was not detected at sampling locations PAT2, PAT6, and PAT8.

In the wet season the general trend suffers some change: PAT5 $>$ PAT11 $>$ PAT9 $>$ PAT2 $>$ PAT8 $>$ PAT10 $>$ PAT4 $>$ PAT6, with no detection at sampling location PAT3.

These sampling sites can be categorized, according to their hydrological conditions, related with flow regime. So, they may represent, approximately, lotic (flowing water) or lentic (standing water) behaviour. In the present case, there are sites located in the stream main channel, typically with flowing water conditions (PAT6, PAT8, PAT10, and PAT11); the others are expected to be in conditions of standing water or low-flow regimen, such as the acidic lagoons (see Fig. 1 for location). However, the hydrological circumstances are not constant along the year. Also, the stream bed shows morphologic variability, which controls the hydraulic conditions. Field observations indicate that from one season to the next, some stream sites acquire similar conditions to the lagoons. So, this may promote physical changes, namely in water movement, depth, and temperature.

Such deviations were clearly observed in relation with seasonality. PAT10 and PAT3 are here explained as examples of these changing flow regimes. The first, located in the main stream, was subject to high flowing water during wet season. However, in summer, the temperature and evaporation raised and this site was transformed into a temporary pool. On the other hand, PAT3 is in an acidic lagoon where physical conditions changed in the wet season, namely: there was an increase in water movement and horizontal current promoted by wind was observed.

Therefore, the observed changes may explain the lower concentrations of Chl $a$ in PAT10 and PAT3 in the wet season (February). High water movement may be a limiting factor for algae, which could justify the differences observed in the wet and dry seasons.

Furthermore, although photosynthesis performance varies, optimal temperatures have been reported around $23^{\circ} \mathrm{C}$ (Kumar et al., 2010). Therefore, it is expected higher biomass production with rising temperature and insolation (Spring and Summer). On the contrary, in winter the decrease of the photo-period and the influence of dilution may reduce the production of chlorophyll $a$, as observed for the two exemplified sites.

Hence, the results of Fig. 5 seems to confirm that warmer and dry conditions of the October campaign promotes chlorophyll production in low-water flow, namely in the acidic lagoons (PAT3, PAT4, PAT5) and temporary pools formed in PAT10 and PAT11. The sites PAT6 and PAT8 showed a different pattern, without detectable chlorophyll in summer. This may be related to the morphology and size of the stream channel, which is highly variable along the course of the river. At these sites, parts of the stream bed are emerged due to water shortage, which limits make unable to keep phytoplankton. Moreover, algal communities should face deposition of particulate matter in such dryness conditions.

Also, sample PAT2, which corresponds to the pit lake (with $120 \mathrm{~m}$ depth) behaves differently. Pit lakes represent unique ecosystems with an aquatic biodiversity mainly controlled by temperature and oxygen stratification (e.g. Lessmann et al., 2000, Sánchez España et al., 2008; Santofimia et al., 2013; Schultze, 2013). Generally, they are characterized by lower temperature and lower light incidence, when compared with other AMDenvironments. Similarly, several authors (Kumar et al., 2016; Lock et al., 1984; Smucker and Vis, 2011) found minor concentrations of Chl ain such limnologic environments. However ecology and the behaviour of primary production in pit lakes still is a controversy issue (Blanchette and Lund, 2016; Geller et al., 2013). In the present case, Chl $a$ was only detectable in February, emphasizing the high seasonal fluctuation referred by Lessmann et al. (2003). In contrast with the other sampling sites, in the pit lake Chl $a$ should result only from activity of suspended algae, since there are not appropriate substrates for attached algal communities. As hypothesis, lower $\mathrm{CO}_{2}$ contribution and strong evapoconcentration of the surface water could inhibit growth of suspended communities in summer. Also, the pit lake should have less contribution of decaying organic matter than the other sampling sites. Therefore, as referred by Bellinger and Sigee (2015), epilimnion concentrations of nutrients are typically reduced at the end of the lake stratification, which may contribute to the observed absence of chlorophyll at the end of summer (October).

The analysis of other photosynthetic pigments, such as pheophytins, could help to understand physiological conditions. It is known that severe conditions for algal development could be evidenced by high levels of degraded pigments, like Feo. However, similarly to Chl $a$, the highest content of Feo occurs in PAT5. This pigment is related to the senescent aged algae, which may represent a subpopulation in equilibrium with the active green algae (Bellinger and Sigee, 2015). Therefore, in the present case, field observations suggest that the Feo may be related with the maturity of the algal mass, and not the result of degradation of chlorophyll.

In contrast to other studies (Luís et al., 2013), in the present case the results suggest higher amount of Chl $a$ in dry season when AMD-indicators reveal higher contamination. In terms of hydrology, Bunn and Arthington (2002) refer the relevance of variation in flow for the biotic composition. The present study suggests higher production of Chl $a$ in the acidic lagoons and summer' pools, in accordance with Breuer et al. (2017) that report lower algal abundance in lotic systems, due to lower residence time. In contrast, another study, also performed in São Domingos (Luís et al., 2019) indicates higher production in a lotic site. However, there are many constraints to effective comparison. In the literature there are references to the difficulty to obtain consistent results of photosynthetic pigments in AMD (e.g. Sabater et al., 2003). The heterogeneity and reactivity of AMD that generates microenvironments (Valente and Gomes., 2009), the degradability of pigments in such acidic environments, and the variability of conditions (physical and chemical, ecological, climate, hydraulics and hydrology) make difficult to compare results from different studies, even when they were performed at the same mining sites. In addition, representative results should be subject to sampling in different seasonal conditions.

As for chemical parameters, consistent results of photosynthetic pigments would depend on dense spatial and temporal sampling, covering the entire hydrological year. Moreover, reliable comparisons are not possible without the use of the same method (e.g., Lorenzen, 1967; Wasmund et al., 2006). Nevertheless, this study is a contribution to increase the knowledge about the importance and behaviour of pigments in different AMD conditions. The findings emphasize the need for continuing research, including future methodological developments for AMD environments.

\subsection{Relation between AMD and photosynthetic activity}

Statistics was applied to assess possible biotic and abiotic relationships in the AMD affected ecosystem. Specifically, factor analysis was used to reduce the universe of influences, and found conditions that effectively affect Chl $a$ in AMD (Fig. 6).

The results of the factor analysis suggest that almost all parameters are related with factor 1 in the positive part. This suggests the role of water-rock interaction involving the metallic sulfides, resulting in sulfate and metals dissolution, with the production of 
Factor 1 Factor 2

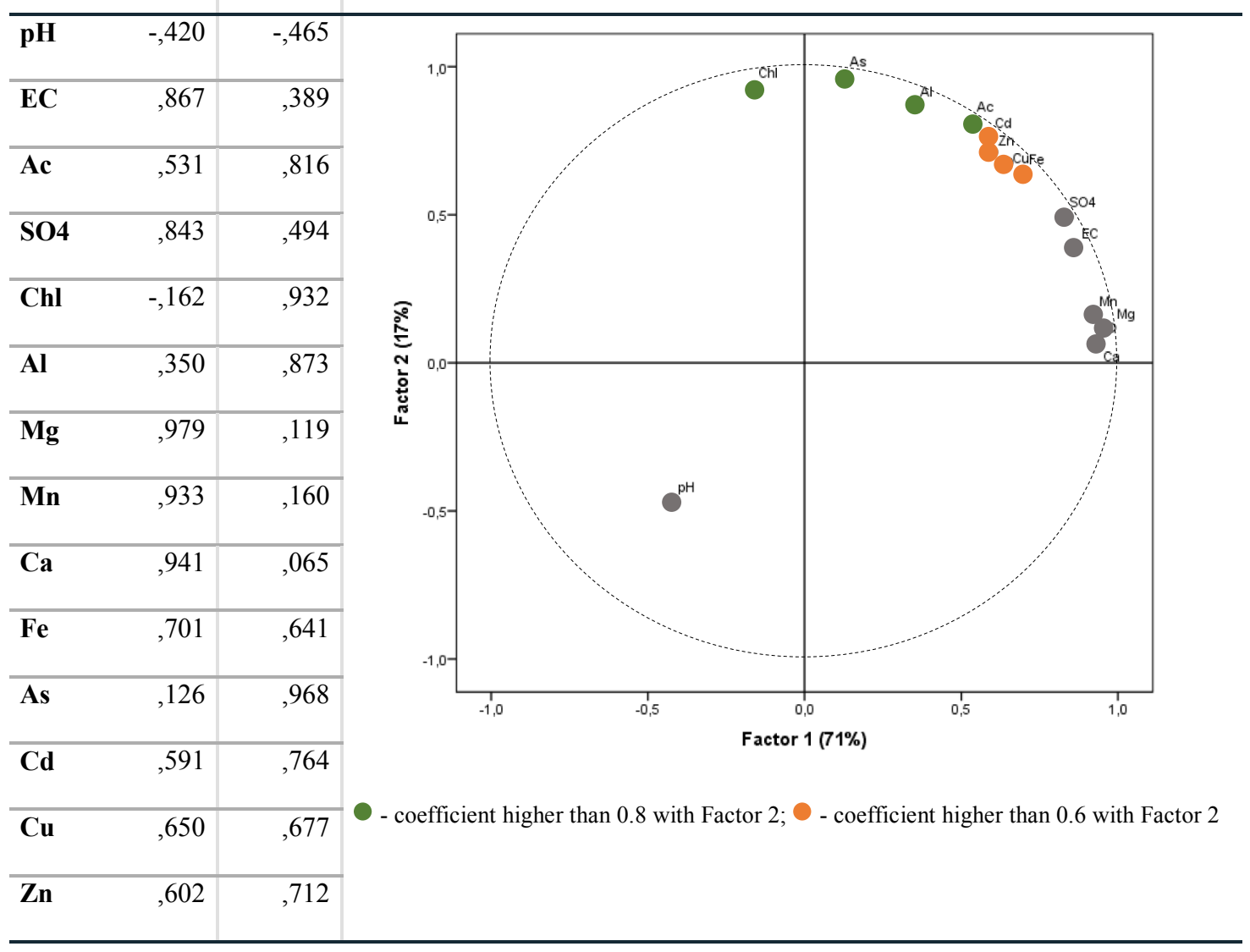

Fig. 6. Results of the factor analysis of the mine water parameters and chlorophyll $a(\mathrm{Chl})$ and respective coefficient matrix.

acidity. This is reflected by the proximity between acidity (Ac) and the most abundant metals in the ore paragenesis (Fe, $\mathrm{Cu}, \mathrm{Zn})$. In such acidic conditions, host rocks also contribute with other metals, like Mg, Mn, and Ca. Moreover, first-flush scenario associated with a rainy event, promoted dissolution of abundant soluble sulfates, like epsomite (Gomes et al., 2017), mobilizing Mg and Ca, which appear highly related with this factor. Thus, factor 1 reflects the contribution of cyclic AMD processes, responsible for liberating acidity, sulfate, and metals.

Chlorophyll $a(\mathrm{Chl})$ shows high and positive correlation with factor 2 , while $\mathrm{pH}$ is in the negative part with moderate correlation. This inverse relation was also detected by Aguilera et al. (2006) in Rio Tinto (Spain). In São Domingos, Luís et al. (2019) emphasize that metals are more relevant than $\mathrm{pH}$, with similar values in two studied sites. In the plot of Fig. 6, the pH is isolated, which suggests its relevance in relation with Chl $a$. Therefore, factor 2 could be associated with photosynthetic activity, responsible for chlorophyll production. This factor proposes that the more acid the environment (low $\mathrm{pH}$ ), the more chlorophyll will be produced.

$\mathrm{Al}$, As, and $\mathrm{Cd}$ are toxic for most of the organisms (Schneider et al., 2018). However, these elements appear strongly related to Chl $a$ (factor 2). This is in accordance with the results discussed above, which revealed higher concentrations of Chl $a$ at the strongly contaminated sites, such as PAT5 and PAT10.

So, this finding suggests that algae communities present mechanisms that prevent effects of toxicity, associated with both $\mathrm{pH}$ and PTE. As observed by other authors (e.g. Romaní and Sabater, 2000; Serra et al., 2009), despite the extreme conditions, photosystem II (PSII) is not damaged, due to adaptation mechanisms of the acidophilic algae (e.g. Serra et al., 2009). As an example of the resistance to AMD conditions, Schultze (2013) discuss the dominance of the acidophilic organisms over the acidotolerant in pit lakes from coal and metals mine in Germany. This author refer similar pH values to the ones measured in São Domingos $(<3.0)$. Several other authors report defense mechanisms and high primary production under conditions that are toxic and hostile for generalist organisms (Gimmler, 2001). Therefore, in the absence of competitors, acidophilic biomass productivity should be high, justifying the higher concentrations of Chl $a$ in the most contaminated sites.

\section{Conclusion}

Hydrochemical data was combined with analyses of photosynthetic pigments in an AMD-affected ecosystem. São Domingos mine was sampled in two seasonal and various hydrological conditions to evaluate trends and relationships between stressful AMD conditions and Chl $a$.

The obtained results for water properties confirmed the strong degree of contamination. Hence, $\mathrm{pH}$ reached a minimum of 2.1, and high concentrations of PTE, like As, $\mathrm{Al}$, and $\mathrm{Cd}$, were also obtained. Seasonality was clearly evidenced, with highest concentrations at the end of the summer (October). Therefore, dryness and evaporation led to increasing metallic and sulfate concentrations. However, exceptions were detected in sites that were sampled immediately after a first rain event (in February). In these cases, rapid first-flush promoted the wash out of soluble sulfate salts and, consequently higher concentrations of AMD-indicators. 
In general, the concentration of Chl $a$ followed the highest concentrations of AMD-indicators. The adaptation mechanisms of the acidophilic algae to the stressful chemical conditions and the absence of competitors allow high biomass production, which is reflected in the highest chlorophyll concentrations.

The concentration of $\mathrm{Chl} a$ revealed seasonal patterns related to physical conditions observed at the sampling sites. Warmer and low water movement promoted chlorophyll production both in acidic lagoons and in temporary pools formed in the stream. These create optimum conditions for photosynthesis and biomass production (high temperature, sun exposure, and high resident time). .

Factor analysis highlights the relationships between hydrochemistry and Chl $a$ through definition of two factors. The first factor, contributing $71 \%$ to the dataset's variability, reflects directly the AMD process, with mobilization of metals and semi-metals from sulfides and sulfates dissolution. The second factor, contributing to $17 \%$ of the variability, represents photosynthetic activity, and suggests the relationship between the $\mathrm{pH}$ and $\mathrm{Chl} a$. Also, higher concentrations of $\mathrm{Chl} a$ were coincident with highest acidity and concentration of PTE, such as As and Al. Therefore, the obtained results indicate that extreme AMD-indicators, in terms of $\mathrm{pH}$ and PTE (As, Al, Cd), should stimulate algal growth.

The results obtained at São Domingos showed that Chl $a$ could be an indicator of the AMD status, allowing predicting seasonal variations of the water quality. In conclusion, the present work could be a step further toward understanding the relationships between biotic and abiotic properties under varying chemistry and flow regimes in AMD environments.

\section{Acknowledgment}

Patrícia Gomes acknowledges FCT (Science and Technology Foundation, Portugal) by the research fellowship under the $\mathrm{POCH}$ (Programa Operacional Capital Humano) supported by the European Social Fund and National Funds of MCTES with reference SFRH/BD/108887/2015. This work was co-funded by the European Union through the European Regional Development Fund, based on COMPETE 2020 - project ICT (UID/GEO/04683/2013) with reference POCI-01-0145-FEDER-007690 and by project Nano-MINENV number 029259 . The authors are also deeply grateful to the anonymous reviewers for their valuable comments and suggestions.

\section{References}

Abreu, M.M., Tavares, M.T., Batista, M.J., 2008. Potential use of Erica andevalensis and Erica australis in phytoremediation of sulphide mine environments: São Domingos, Portugal. J. Geochem. Explor. 96, 210-222 doi.org/10.1016/ j.gexplo.2007.04.007.

Abreu, M.M., Batista, M.J., Magalhães, M.C., Matos, J.X., 2010. Acid mine drainage in the Portuguese iberian pyrite Belt. In: Robinson, Brock C. (Ed.), Mine Drainage and Related Problems. Nova Science Publishers, New York, p. 70.

Aguilera, A., Manrubia, S.C., Gomez, F., Rodriguez, N., Amils, R., 2006. Eukaryotic community distribution and its relationship to water physicochemical parameters in an extreme acidic environment, Rio Tinto (Southwestern Spain). Appl. Environ. Microbiol. 72, 5325-5330.

Aldous, P.J., 1987. The Groundwater Hydrology of an Abandoned Coal Mined Aquifer - A Case Study from the Forest of Dean Coalfield. Univ. of Bristol, Bristol, p. 298

Alpers, C.N., Nordstrom, D.K., Thompson, J.M., 1994. Seasonal variations of Zn/Cu ratios in acid mine water from Iron Mountain, California. In: Alpers, C.N., Blowes, D.W. (Eds.), Environmental Geochemistry of Sulfide Oxidation, vol. 550. American Chemical Society Symposium Series, pp. 324-344.

Amils, R., González-Toril, E., Aguilera, A., Rodríguez, N., Fernández-Remolar, D., Gómez, F., García-Moyano, A., Malki, M., Oggerin, M., Sánchez-Andrea, I., Sanz, J.L., 2011. From Río Tinto to mars. The terrestrial and extraterrestrial ecology of acidophiles. Adv. Appl. Microbiol. https://doi.org/10.1016/B978-0-12387044-5.00002-9.

APHA, 2012. Standard Methods for the Examination of Water and Wastewater, twentieth ed. American Public Health Association, American Water Works Association, Water Environment Federation, Washington DC.

ASTM, 1992. Standard Practice for Cleaning Laboratory Glassware, Plasticware and Equipment Used in Microbiological Analysis ASTM 5245), vol. 5. ASTM
Committee on Standards. American Society for Testing and Materials.

Barriga, F.J.A.S., 1990. Metallogenesis in the iberian pyrite Belt. In: Dallmeyer, R.D. Martinez-Garcia, E. (Eds.), Pre-Mesozoic Geology of Iberia. Springer-Verlag, Berlin, Heidelberg, New York, pp. 369-379.

Bellinger, G.E., Sigee, D.C., 2015. Freswater Algae, second ed. Wiley-Blacwell, Chichester, West Sussex.

Blanchette, M., Lund, M., 2016. Pit lakes are a global legacy of mining: an integrated approach to achieving sustainable ecosystems and value for communities. Curr. Opin. Environ. Sustain. 23, 28-34.

Boyer, J., Kelble, C., Ortner, P., Rudnick, T., 2009. Phytoplankton bloom status: chlorophyll a biomass as an indicator of water quality condition in the southern estuaries of Florida, USA. Ecol. Indicat. 95, 556-567.

Breuer, F., Janz, P., Farrelly, E., Ebke, K., 2017. Environmental and structural factors influencing algal communities in small streams and ditches in central Germany. J. Freshw. Ecol. 32, 65-83. https://doi.org/10.1080/02705060.2016.1241954.

Bunn, S., Arthington, A., 2002. Basic principles and ecological consequences of altered flow regimes for aquatic biodiversity. Environ. Manag. 30, 492. https:// doi.org/10.1007/s00267-002-2737-0.

Corcoll, N., Bonet, B., Morin, S., Tlili, A., Leira, M., Guasch, H., 2012. The effect of metals on photosynthesis processes and diatom metrics of biofilm from a metal-contaminated river: a translocation experiment. Ecol. Indicat. 18, 620-631 doi.org/10.1016/j.ecolind.2012.01.026.

De Vallejuelo, S.F.O., Gredilla, A., da Boit, K., Teixeira, E.C., Sampaio, C.H., Madariaga, J.M., Silva, L.F., 2017. Nanominerals and potentially hazardous elements from coal cleaning rejects of abandoned mines: environmental impact and risk assessment. Chemosphere 169, 725-733.

Dutta, M., Saikia, J., Taffarel, S.R., Waanders, F.B., de Medeiros, D., Cutruneo, C.M., Saikia, B.K., 2017. Environmental assessment and nano-mineralogical characterization of coal, overburden and sediment from Indian coal mining acid drainage. Geosci. Front. 8, 1285-1297.

European Committee for Standardization, 2003. Water Quality - Guidance Standard for the Routine Sampling and Pretreat- Ment of Benthic Diatoms from Rivers. European Standard EN 13946. European Committee for Standardization, Brussels, p. 14.

García-Lorenzo, M.L., Marimón, J., Navarro-Hervás, M.C., Pérez-Sirvent, C., MartínezSánchez, M.J., Molina-Ruiz, J., 2016. Impact of acid mine drainages on surficial waters of an abandoned mining site. Environ. Sci. Pollut. Res. https://doi.org/ 10.1007/s11356-015-5337-2.

Geller, W., Schultze, M., Kleinmann, R., Wolkersdorfer, C., 2013. Acidic Pit Lakes the Legacy of Coal and Metal Surface Mines. Springer, Heidelberg.

Gomes, P., Valente, T.M., 2019. Physical and chemical conditions for colonization by Euglena mutabilis: case studies in two acid mine drainage sites in: Wolkersdorfer, Ch. In: Khayrulina, E., Polyakova, S., Bogush, A. (Eds.), Mine Water: Technological and Ecological Challenges. IMWA, pp. 420-424, 2019.

Gomes, P., Valente, T., Grande, J.A., Cordeiro, M., 2017. Occurrence of sulphate efflorescences in São Domingos mine. Comunicações Geológicas 104, 83-89. http://www.lneg.pt/iedt/unidades/16/paginas/26/30/247.

Gomes, P., Valente, T.M., Cordeiro, M., Moreno, F., 2019. Hydrochemistry of pit lakes in the Portuguese sector of the iberian pyrite Belt. In: E3S Web of Conferences. EDP Sciences. https://doi.org/10.1051/e3sconf/20199809007, 98, WRI-16, 09007 (2019).

Gomes, P., Valente, T.M., Pereira, P., 2018. Addressing quality and usability of surface water bodies in semi-arid regions with mining influences. Environ. Process. 5, 707-725 doi.org/10.1007/s40710-018-0329-0.

Gimmler, 2001. Acidophilic and acidotolerant algae. In: Rai, L.C., Gaur, J.P. (Eds.), Algal Adaptation to Enviromental Stresses. Springer, Heidelberg, pp. 259-321.

Inverno, C., Diez-Montes, A., Rosa, C., García-Crespo, J., Matos, J., García-Lobón, J.L., Carvalho, J., Bellido, F., Castello-Branco, J.M., Ayala, C., Batista, M.J., Rubio, F., Granado, I., Tornos, F., Oliveira, J.T., Rey, C., Araújo, V., Sánchez-García, T. Pereira, Z., Represas, P., ar, Solá, Sousa, P., 2015. In: Weihed, P. (Ed.), Introduction and Geological Settings (Chapter 9) N: 3D, 4D and Predictive Modelling of Major Mineral Belts in Europe: Part IV: the Iberian Pyrite Belt and Ossa-Morena Zones. Springer-Verlang, Berlin.

IPMA, 2018. (Instituto Português do Mar e da Atmosfera) (consulted in August 2018). www.ipma.pt.

Keith, C.N., Vaughan, D.J., 2000. Mechanisms and rates of sulphide oxidation in relation to the problems of acid rock (mine) drainage. In: Campbell, L.S., Valsami-Jones, E., Batchelder, M. (Eds.), Environmental Mineralogy: Microbial Interactions, Anthropogenic Influences, Contaminated Land and Waste, pp. 117-139. The Mineralogical Society Series, 9.

Kumar, A., Ergas, S., Yuan, X., Sahu, A., Zhang, Q., Dewulf, J., Malcata, F.X. VanLangenhove, $\mathrm{H}$., 2010. Enhanced $\mathrm{CO}_{2}$ fixation and biofuel production via microalgae: recent developments and future directions. Trends Biotechnol. 28, $371-380$

Kumar, R.N., McCullough, C.D., Lund, M.A., Larranaga, S.A., 2016. Assessment of factors limiting algal growth in acidic pit lakes-a case study from Western Australia, Australia. Environ. Sci. Pollut. Res. 23, 5915-5924. https://doi.org/ 10.1007/s11356-015-5829-0.

Lessmann, D., Fyson, A., Nixdorf, B., 2000. Phytoplankton of the extremely acidic mining lakes of Lusatia (Germany) with $\mathrm{pH}<3$. Hydrobiologia 433, 123-128.

Lessmann, D., Fyson, A., Nixdorf, B., 2003. Experimental eutrophication of a shallow acidic mining lake and effects on the phytoplankton. Hydrobiologia 509 753-758.

Levings, C.D., Varela, D.E., Mehlenbacher, N.M., Barry, K.L., Piercey, G.E., Guo, M., Harrison, P.J., 2005. Effect of an acid mine drainage effluent on phytoplankton 
biomass and primary production at Britannia Beach, Howe Sound, British Columbia. Mar. Pollut. Bull. 50, 1585-1594. https://doi.org/10.1016/ j.marpolbul.2005.06.032.

Lock, M., Wallace, R., Costerton, J., Ventullo, R., Charlton, S., 1984. River epilithon: toward a structural-functional model. Oikos 42,10-22. https://doi.org/10.2307/ 3544604.

Lorenzen, C.J., 1967. Determination of chlorophyll and pheo-pigments - spectrophotometric equations. Limnol. Oceanogr. 12, 343-346.

Luís, A.T., Coelho, H., Almeida, S.F.P., da Silva, E.F., Serôdio, J., 2013. Photosynthetic activity and ecology of benthic diatom communities from streams affected by Acid Mine Drainage (AMD) in pyritic mines. Fundam. Appl. Limnol./Arch. Hydrobiol. 182, 47-59. https://doi.org/10.1127/1863-9135/2013/0370.

Luís, A.T., Teixeira, M., Durães, N., Pinto, R., Almeida, S., Ferreira da Siva, E., Figueira, E., 2019. Extremely acidic environment: biogeochemical effects on algal biofilms. Ecotoxicol. Environ. Saf. 177, 124-132. https://doi.org/10.1016/ j.ecoenv.2019.04.001.

Matos, J.X., Pereira, Z., Baptista, M.J., Oliveira, D., 2012. São Domingos mining site iberian pyrite Belt. In: The International Symposium on Environmenta Geochemistry, Aveiro, 15th-21th July.

McKibben, A.A., Barnes, H.L., 1986. Oxidation of pyrite in low temperature acidic solutions: rate laws and surface textures. Geochem. Cosmochim. Acta 50, 1509-1520.

Moncur, M., Ptacek, C., Blowes, D., 2015. The occurrence and implications of efflorescent sulfate minerals at the former sherritt-gordon $\mathrm{Zn}-\mathrm{Cu}$ mine, Sherridon, Manitoba, Canada. Can. Mineral. 53, 961-977. https://doi.org/10.3749/ canmin.1500092.

Nordin, A.P., Da Silva, J., De Souza, C., Niekraszewicz, L.A.B., Dias, J.F., Da Boit, K, Oliveira, M.L.S., Grivicich, I., Garcia, A.L., Silva, L.F., Da Silva, F.R., 2018. In vitro genotoxic effect of secondary minerals crystallized in rocks from coal mine drainage. J. Hazard Mater. 346, 263-272.

Nordstrom, D.K., 2009. Acid rock drainage and climate change. J. Geochem. Explor. 100, 97-104. https://doi.org/10.1016/j.gexplo.2008.08.002.

Nordstrom, D.K., Southam, G., 1997. Geomicrobiology of sulfide mineral oxidation. In: Banfield, J.F., Nealson, K.H. (Eds.), Geomicrobiology: Interactions between Microbes and Minerals, vol. 35. Rev Mineral, pp. 361-390.

Novis, P.M., Harding, J.S., 2007. Extreme acidophiles. In: Seckbach, J. (Ed.), Algae and Cyanobacteria in Extreme Environments, Cellular Origin, Life in Extreme Habitats and Astrobiology, vol. 11. Springer, Dordrecht. https://doi.org/10.1007/978 1-4020-6112-7_24.

Olías, M., Canovas, C.R., Basallote, M.D., Macías, F., Pérez-López, R., Moreno González, R., Millán-Becerro, R., Nieto, J.M., 2019. Causes and impacts of a mine water spill from an acidic pit lake (Iberian Pyrite Belt). Environ. Pollut. 250, 127-136. https://doi.org/10.1016/j.envpol.2019.04.011.

Pérez-Sirvent, C., Hernández-Pérez, C., Martínez-Sánchez, M.J., García-Lorenzo, M.L Bech, J., 2016. Geochemical characterisation of surface waters, topsoils and efflorescences in a historic metal-mining area in Spain. J. Soils Sediments. https:// doi.org/10.1007/s11368-015-1141-3.

Perry, E.F., Rauch, H., 2013. Estimating water quality trends in abandoned coal mine-pools. In: West Virginia Mine Drainage Task Force Meeting, March 26-27, 2013, Morgantown, WV.

Pridmore, R.D., Hewitt, E., 1984. Chlorophyll a as an indicator of phytoplankton cell volume in 12 lakes, North Island, New Zealand. N. Z. J. Bot. 22, 295-301. https:// doi.org/10.1080/0028825X.1984.10425257.

Romaní, A.M., Sabater, S., 2000. Influence of algal biomass on extracellular enzyme activity in river biofilms. Microb. Ecol. 40, 16-24. https://doi.org/10.1007/ s002480000041.

Sabater, S., Buchaca, T., Cambra, J., Catalan, J., Guasch, H., Ivorra, N., Muñoz, I.,
Navarro, E., Real, M., Romaní, A., 2003. Structure and function of benthic algal communities in an extremely acid river. J. Phycol. 39, 481-489. https://doi.org/ 10.1046/j.1529-8817.2003.02104.x.

Sáez, R., Pasqual, E., Toscano, M., Almodovar, G.R., 1999. The Iberian type of volcanosedimentary massive sulphide deposits. Miner. Depos. 34, 549-570. https:// doi.org/10.1007/s001260050220.

Sánchez España, J., López-Pamo, E., Santofimia, E., Diez Ercilla, M., 2008. The acidic mine pit lakes of Iberian Pyrite Belt: an approach to their physical limnology and hydrogeochemistry. Appl. Geochem. 23, 1260-1287.

Sánchez-Peña, N.E., Narváez-Semanate, J.L., Pabón-Patiño, D., Fernández-Mera, J.E., Oliveira, M.L., Da Boit, K., Tutikian, B., Crissien, T., Pinto, D., Serrano, I., Ayala, C., Duarte, A., Ruiz, J., Silva, L.F., 2018. Chemical and nano-mineralogical study for determining potential uses of legal Colombian gold mine sludge: experimental evidence. Chemosphere 191, 1048-1055.

Santofimia, E., González-Toril, E., López-Pamo, E., Gomariz, M., Amils, R., Aguilera, A., 2013. Microbial diversity and its relationship to physicochemical characteristics of the water in two extreme acidic pit lakes from the iberian pyrite Belt (SW Spain). PLoS One 8, e66746. https://doi.org/10.1371/ journal.pone.0066746.

Schneider, S.C., Oulehle, F., Krám, P., Hruška, J., 2018. Recovery of benthic algal assemblages from acidification: how long does it take, and is there a link to eutrophication? Hydrobiologia 805, 33-47. https://doi.org/10.1007/s10750017-3254-8.

Schultze, M., 2013. Limnology of pit lakes. In: Geller, W., Schultze, M., Kleinmann, R., Wolkersdorfer, C. (Eds.), Acidic Pit Lakes. Environmental Science and Engineering (Environmental Engineering). Springer, Berlin, Heidelberg.

Serra, A., Corcoll, N., Guasch, H., 2009. Copper bioaccumulation and toxicity in fluvial periphyton: the influence of exposure history. Chemosphere 74, 633-664.

Silva, L.F.O., Fdez-Ortiz De Vallejuelo, S., Martinez-Arkarazo, I., Castro, K., Oliveira, Marcos L.S., Sampaio, C. De Brum, I., De Leão, F., Taffarel, S. Madariaga, J., 2013. Study of environmental pollution and mineralogical characterization of sediment rivers from Brazilian coal mining acid drainage. Sci. Total Environ. 447, 169-178.

Singer, P.C., Stumm, W., 1970. Acidic mine drainage - rate-determining step. Science 167 (3921), 1121-1123. https://doi.org/10.1126/science.167.3921.1121.

Smucker, N.J., Vis, M.L., 2011. Contributions of habitat sampling and alkalinity to diatom diversity and distributional patterns in streams: implications for conservation. Biodivers. Conserv. 20, 643-661.

Valente, T.M., Gomes, C.L., 2007. The role of two acidophilic algae as ecological indicators of acid mine drainage sites. J. Iber. Geol. 33, 283-294.

Valente, T.M., Gomes, C.L., 2009. Fuzzy modelling of acid mine drainage environments using geochemical, ecological and mineralogical indicators. J. Environ. Geol. 57, 653-663.

Valente, T.M., Rivera, M.J., Almeida, S.F.P., Delgado, C., Gomes, P., Grande, J.A., de la Torre, M.L., Santisteban, M., 2016. Characterization of water reservoirs affected by acid mine drainage: geochemical, mineralogical, and biological (diatoms) properties of the water. Environ. Sci. Pollut. Res. 23, 6002-6011. https://doi.org/ $10.1007 / \mathrm{s} 11356-015-4776-0$.

Wasmund, N., Topp, I., Schories, D., 2006. Optimising the storage and extraction of chlorophyl samples. Oceanologia 48, 125-144.

Wolkersdorfer, C., 2008. Water Management at Abandoned Flooded Underground Mines - Fundamentals, Tracer Tests, Modelling, Water Treatment. Springer, Heidelberg.

Younger, P.L., 1997. The longevity of minewater pollution - a basis for decisionmaking. Sci. Total Environ. 194-195, 457-466. https://doi.org/10.1016/S00489697(96)05383-1. 